\title{
PENGARUH CUSTOMER PERCEPTION TERHADAP MINAT BELI KONSUMEN MELALUI MULTIATTRIBUTE ATTITUDE MODEL PADA PRODUK MAKANAN ORGANIK
}

\author{
Yerosa Dian Putri Limantara \\ Praktisi Pemasar Makanan Organik \\ di Surabaya \\ E-mail: yerosa.dian@gmail.com
}

\begin{abstract}
Abstrak: Penelitian membahas customer perception yang membentuk multiattribute attitude model dalam pengaruhnya terhadap minat beli konsumen pada produk makanan organik. Sampel penelitian ini berjumlah 100 responden dari masyarakat Kota Surabaya dengan kategori usia remaja akhir (17-25 tahun), dewasa muda (26-35 tahun), dan dewasa akhir (36-45 tahun). Pengukuran dilakukan dengan menggunakan metode path analysis dari variabel customer perception dengan dimensi kesehatan (X1), rasa (X2), keseimbangan ekosistem (X3), kualitas produk (X4), harga (X5), dan food safety (X6) sebagai variabel independen; variabel multiattribute attitude model sebagai variabel intervening dengan dimensi kepercayaan pada produk $(Y 1)$, kesadaran akan kesehatan dan lingkungan $(Y 2)$, dan atribut produk itu sendiri $(Y 3)$; sedangkan variabel minat beli sebagai variabel dependen diukur dengan dimensi minat transaksional $(Z 1)$, minat referensi $(Z 2)$, minat preferensi (Z3), dan minat eksploratif (Z4). Hasil penelitian ini menunjukkan: (1) customer perception memiliki pengaruh positif terhadap multiattribute attitude model; (2) variabel multiattribute attitude model memiliki pengaruh positif terhadap minat beli konsumen pada produk makanan organik.
\end{abstract}

Kata kunci: Persepsi, Sikap, Minat Beli, Makanan Organik.

\begin{abstract}
The study discusses customer perception that forms a multiattribute model in its influence on customer purchase intention in organic food products. The sample of this stucy is 100 respondents who lives in Surabaya with ages category: final teen (17-25 years old), young adult (26-35 years old), and final adult (36-45 years old). Measurement were taken by path analysis method from the dimensions of customer perception variable health (X1), taste (X2), ecosystem balance (X3), product quality (X4), price (X5), and food safety (X6) as independent variable; multiattribute attitude model as intervening variable with dimensions of trust in product (Y1), awareness of health and environment (Y2), and product attributes itself (Y3); whereas purchase intention as dependent variable is measured by the dimension of transactional interest (Z1), reference interest (Z2), preference interest (Z3), and explorative interest (Z4). The results of this study indicate (1) customer perception has a positive influence on multiattribute attitude model; (2) multiattribute attitude model has a positive influence on purchase intention in organic food products.
\end{abstract}

Keywords: Perception, Attitude, Purchase Intention, Organic Food

\section{PENDAHULUAN}

Makanan merupakan salah satu kebutuhan pokok manusia untuk kelangsungan hidupnya, namun dewasa ini semakin banyak produk makanan yang tidak sehat karena mengandung zat-zat kimia yang dapat mempengaruhi kesehatan manusia. Karena itu, dewasa ini makanan organik menjadi salah satu jalan keluar untuk mengatasi masalah kesehatan tersebut. Makanan organik dinilai lebih sehat karena pembudidayaannya tidak menggunakan bahan kimia.

Seiring dengan meningkatnya kualitas pendidikan di Indonesia dan kemudahan untuk mengakses informasi mengenai kesehatan, mengakibatkan meningkatnya kesadaran masyarakat akan bahaya mengkonsumsi produk makanan non organik. Menurut Sekjen Masyarakat Pertanian Organik Indonesia (Maporina), Ali Zum Mashar, "Konsumen semakin sadar dan selektif atas segi kualitas kesehatan produk pertanian. Mereka kini lebih suka mengonsumsi produk organik ketimbang yang menggunakan bahan an-organik." (Indonesia Organic Alliance, 2017). Hal ini menyebabkan timbulnya pergeseran pola konsumsi masyarakat dari makanan non organik menjadi makanan organik.

Konsumsi makanan organik terus mengalami peningkatan dari tahun ke tahun. Menurut WTO (World Trade Organisastion), pemilihan konsumen terhadap produk organik dunia bertumbuh mencapai rata-rata $20 \%$ per tahun (dalam Yayasan Pengembangan Kemanusiaan Donders, 2015). Mengingat peningkatan konsumsi pada makanan organik, ada perubahan pola makan konsumen yang dapat dilihat melalui pola sarapan seha, sehingga hal itu memunculkan tren gaya hidup yang baru. Hal ini membuat banyak produsen mulai menggeser produknya dari non organik menjadi organik. Selain itu ada juga beberapa catering service yang secara khusus menyediakan menu makanan organik. 
Minat beli masyarakat terhadap makanan organik dipengaruhi oleh kesadaran akan hidup sehat, yang merupakan salah satu dimensi dari persepsi konsumen. Dimensi lain yang juga turut mempengaruhi minat beli adalah keamanan, ramah lingkungan dan kesejahteraan hewan, serta kualitas produk (Wee, Ariff, Zakuan, \& Tajudin, 2014). Persepsi diatas akan mempengaruhi sikap konsumen, yang akhirnya sikap konsumen juga mempengaruhi minat beli terhadap makanan organik. Berdasarkan penelitian yang dilakukan oleh (Asiegbu, Powei Daubry M, \& Iruka, 2012), sikap sangat mempengaruhi perilaku konsumen dalam membeli produk. Sikap dipercayai memiliki pengaruh yang besar pada strategi pemasaran dan dapat membantu meningkatkan penjualan karena mengetahui keinginan/ kebutuhan konsumen sehingga dapat meningkatkan niatan beli konsumen terhadap suatu produk (2012, p. 48).

Minat beli konsumen secara tidak langsung juga akan mempengaruhi penjualan makanan organik. Oleh karena itu, produsen/penjual makanan organik perlu mengetahui persepsi konsumen yang dapat mempengaruhi sikap konsumen terhadap makanan organik untuk dapat meningkatkan penjualan/produknya. Hal ini akan membantu produsen/penjual makanan dalam negeri untuk dapat menghasilkan produk yang mampu memenuhi keinginan dan kebutuhan konsumen.

Kesadaran konsumen akan kesehatan dengan mengonsumsi makanan organik sudah tinggi, namun pada prakiknya belum sepenuhnya terdapat konsistensi antara niat beli dengan perilaku konsumsi (Novandari, 2011; Vermeir \& Verbeke, 2006). Oleh karena itu, faktor-faktor diatas mempunyai hubungan positif pada niatan beli konsumen makanan organik. Penelitian ini berusaha untuk menggali lebih dalam mengenai hubungan-hubungan tersebut.

\section{LANDASAN TEORI}

\section{Makanan Organik}

Makanan organik adalah sebuah produk makanan yang bahan dasarnya melalui sebuah proses pembudidayaan yang alami dan diolah dengan cara yang alami juga. Bahan dasar makanan organik ada pada tanaman dan hewan sama seperti makanan konvensional lainnya. Perbedaannya adalah kedua bahan ini diproduksi/dibudidayakan secara alami, yaitu tidak menggunakan obat-obatan buatan (fertilisasi, pestisida, hormon pertumbuhan), menghindari penggunaan organisme dari rekayasa genetika (Genetically Modified Organism), dan/atau pewarna dan perasa buatan sehingga lebih aman dikonsumsi dan baik untuk kesehatan.

\section{Customer Perception}

Dalam mempertimbangkan pembelian produk, ada beberapa tahap yang perlu dilalui dalam proses pembelian (Kotler \& Amstrong, 2010). Pembeli akan memilah keinginan dan kebutuhannya ketika dihadapkan dengan suatu keputusan sehingga membutuhkan sebuah persepsi yang tepat sebagai salah satu hal yang mendukung keputusan pembelian. Persepsi seseorang pada umumnya terbentuk dari fenomena, kebutuhan, keinginan, nilai dan pengalaman. Dalam pemasaran, seorang pemasar perlu mengetahui persepsi seseorang, apa yang orang itu pikirkan, karena apa yang dipikirkan oleh konsumen akan berimbas pada tindakan mereka selanjutnya (Schiffman \& Kanuk, 2007). Dengan kata lain, persepsi adalah sebuah pemikirian mengenai berbagai macam stimulan (warna, aroma, suara, rasa, perasaan) yang diterima oleh individu untuk mengevaluasi suatu produk. Persepsi konsumen pada makanan organik memiliki dimensi kesehatan, rasa, keseimbangan ekosistem, kualitas produk, harga, dan food safety.

\section{Multiattribute Attitude Model}

Sikap merupakan sebuah output yang keluar dari pembelajaran/pengalaman dan persepsi seseorang (Schiffman \& Kanuk, 2007). Pengalaman dan persepsi konsumen akan membentuk sebuah kecenderungan tertentu dalam berperilaku secara konsisten ketika konsumen hendak merespon suatu stimulan. Sikap dapat bertahan lama, namun dapat juga berubah jika ada pengalaman baru yang didapat oleh konsumen tersebut. Lebih menariknya lagi, sikap merupakan sebuah refleksi dari sebuah objek, sehingga dapat dikatakan bahwa setiap konsumen yang ada pasti mempunyai sikap yang berbeda-beda pada satu objek yang sama. Sangat penting bagi pemasar untuk mengetahui sikap-sikap konsumen tersebut, karena pada saat tertentu, konsumen dapat bersikap tidak konsisten yang berimbas pada perpindahan dari satu merk ke merk lainnya (Asiegbu et al., 2012; Peter \& Olson, 2008; Schiffman \& Kanuk, 2007; Solomon, 2004; Yang, Al-shaaban, \& Nguyen, 2014). Dengan kata lain, sikap merupakan sebuah evaluasi yang dilakukan oleh konsumen melalui pembelajaran dan pengalaman terhadap sebuah objek, baik secara positif maupun negatif, dan tertanam pada benak konsumen, sehingga menimbulkan kekonsistenan pada setiap tindakan yang dilakukan oleh konsumen. Sikap konsumen dibedakan dalam beberapa macam model, salah satunya adalah multiattribute attitude models yang akan dibahas pada penelitian ini. Namun hanya satu model yang akan dibahas dalam penelitian ini, yakni the attitude toward object model. 
Attitude toward object adalah sebuah model pengukuran untuk mengukur sikap konsumen pada suatu produk dengan cara mengevaluasi kualitas dan kepercayaan yang dimiliki konsumen pada produk tersebut (Schiffman \& Kanuk, 2007). Dengan kata lain, konsumen biasanya mempunyai sikap yang baik pada produk tertentu yang dipercayai mempunyai keuntungan positif bagi konsumen. Namun sebaliknya, mereka juga mempunyai sikap yang tidak baik pada produk tertentu ketika mereka merasa bahwa terlalu banyak atribut yang tidak sesuai dengan keinginan mereka (keuntungan negatif). Sikap konsumen pada makanan organik memiliki dimensi kepercayaan produk, kesadaran akan kesehatan dan lingkungan, dan atribut pada produk itu sendiri.

\section{Purchase Intention}

Minat beli merupakan sebuah kunci penting bagi konsumen ketika mereka sedang mempertimbangkan dan mengevaluasi produk tertentu. Minat beli adalah sebuah alat yang efektif dalam memprediksi proses pembelian. Saat konsumen memutuskan untuk membeli sebuah produk, mereka secara tidak langsung diarahkan oleh keinginan/minatnya. Menurut Wee et al., (2014), minat beli mewakili pemikiran konsumen untuk membeli sesuatu. Bagaimanapun juga, minat beli tidak bisa disamakan dengan pembelian yang aktual, karena minat beli dapat diganggu oleh rangsangan internal maupun external seperti harga, kualitas barang, dan lain sebagainya (Jaafar, Lalp, \& Mohamed Naba, 2013). Minat beli mempunyai dimensi minat transaksional, minat referensial, minat preferensial, dan minat eksploratif.

\section{Penelitian Terdahulu}

Pada penelitian sebelumnya yang dilakukan oleh Kim \& Chung, (2011) dengan judul "Consumer purchase intention for organic personal care products", peneliti meneliti bagaimana persepsi konsumen mengenai produk perawatan diri membentuk suatu sikap tertentu yang memperngaruhi minat beli konsumen terhadap produk tersebut. Kesimpulannya adalah bahwa persepsi yang berupa persepsi kesehatan, linkungan, dan penampilan mempunyai pengaruh yang positif terhadap sikap konsumen. Begitu juga sikap konsumen yang terbangun dari persepsi konsumen, mempunyai pengaruh yang positif terhadap minat beli konsumen. Peneliti menunjukkan bahwa dengan membentuk sikap yang positif terhadap produk perawatan organik dapat meningkatkan minat beli konsumen, sehingga dapat menjadi pertimbangan para penjual produk tersebut.

\section{Kerangka Konseptual}

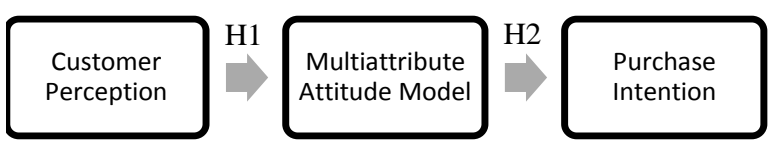

Gambar 1. Kerangka Konseptual

\section{Hipotesa}

$\mathrm{H}_{1}$ : Persepsi konsumen berpengaruh secara positif terhadap sikap konsumen pada makanan organik.

$\mathrm{H}_{2}$ : Sikap konsumen berpengaruh secara positif terhadap minat beli pada makanan organik.

\section{METODOLOGI PENELITIAN}

\section{Populasi dan Sampel}

Populasi dalam penelitian ini adalah masyarakat Surabaya yang belum pernah mengkonsumsi makanan organik tetapi mempunyai pengetahuan mengenai makanan organik. Dalam penelitian ini, teknik pengambilan sampel menggunakan quota sampling berdasarkan kelompok usia tertentu, yaitu remaja akhir (17-25 tahun), dewasa muda (26-35 tahun), dan dewasa akhir (36-45) tahun.

Jumlah total sampel yang digunakan untuk penelitian ini adalah 100 sampel dengan 25 orang responden usia remaja akhir, 41 orang responden usia dewasa muda, dan 34 orang responden usia dewasa akhir yang tingal di kota Surabaya.

\section{Definisi Operasional Variabel}

\section{Persepsi (X)}

a. Kesehatan (X1) merupakan suatu keadaan dimana tubuh sedang dalam keadaan baik dan tidak sakit. Konsumen akan mengolah, mengevaluasi makanan organik dengan melihat sejauh mana makanan organik tersebut dapat mempengaruhi kesehatannya.

b. Rasa (X2) merupakan sebuah tanggapan dari indra terhadap rangsangan saraf, seperti manis, pahit, masam terhadap indra pengecap, atau panas, dingin, nyeri terhadap indra perasa, sehingga konsumen dapat mengevaluasi tingkat kelezatan makanan organik.

c. Keseimbangan Ekosistem (X3) mengacu pada terjaganya kestabilan ekosistem karena tidak ada bahan kimia tertentu yang dapat memba- 
hayakan baik tanaman maupun hewan di sekitar lahan pertanian.

d. Kualitas Produk (X4) mengacu pada tingkat baik buruknya makanan organik dimata konsumen.

e. Harga (X5) berhubungan dengan nilai uang yang dikeluarkan oleh konsumen apakah sesuai dengan manfaat yang didapatkan dari mengkonsumsi makanan organik.

f. Food Safety (X6) mengacu pada keamanan dalam mengkonsumsi makanan organik.

2. $\operatorname{Sikap}(\mathrm{Y})$

a. Kepercayaan pada Produk (Y1) mengacu pada anggapan atau keyakinan konsumen pada makanan organik.

b. Kesadaran akan Kesehatan dan Lingkungan (Y2) mengacu pada pemikiran konsumen pada perkembangan lingkungan dan kesehatan diri sendiri.

c. Atribut dari Produk itu Sendiri (Y3) mengacu pada sifat yang lekat pada makanan organik.

3. Minat Beli (Z)

a. Minat transaksional dimana konsumen akan melakukan pembelian nyata pada makanan organik.

b. Minat referensial dimana konsumen akan menyarankan teman/kerabat dan orang lain untuk mengkonsumsi makanan organik.

c. Minat preferensial dimana konsumen akan terus membeli makanan organik sebagai konsumsi sehari-hari.

d. Minat eksploratif dimana konsumen akan mencari informasi yang lebih baru lagi mengenai makanan organik.

\section{Alat Analisa Data}

\section{Path Analysis}

Pengujian hipotesis dalam penelitian ini menggunakan teknik path analysis untuk menunjukkan adanya hubungan yang kuat antar variabel yang diuji. Teknik path analysis digunakan untuk melukiskan dan menguji model hubungan antar variabel yang mempunyai bentuk sebab akibat. Pengujian statistik pada model path analysis dilakukan dengan menggunakan metode partial least square atau biasa dikenal dengan PLS. Salah satu kelebihan PLS adalah mampu menangani model yang kompleks dengan multiple independen dan dependen dengan banyak indikator, dapat digunakan pada sampel dengan jumlah yang kecil, dan tidak ada data error atau missing value (Abdillah \& Hartono, 2015).

\section{T-test}

Pengujian hipotesis untuk variabel intervening adalah dengan menggunakan prosedur t-test. T-test digunakan untuk mendapatkan nilai t-statistik yang diperlukan apabila peneliti ingin melakukan uji hipotesis, sehingga peneliti dapat mengatakan pengaruh sebuah variabel dapat dikatakan memiliki pengaruh yang signifikan atau tidak. T-test dilakukan dengan menggunakan metode bootstrapping yang merupakan suatu proses pengujian re-sampling yang dilakukan oleh sistem komputer untuk mengukur akurasi pada sample estimate. Apabila nilai bootstrap lebih dari (>) 1.96 maka dinyatakan bahwa variabel tersebut memiliki pengaruh yang signifikan sedangkan apabila nilai bootstrap lebih rendah $(<)$ dari 1.96, maka dinyatakan pengaruh variabel tersebut lemah.

\section{Statistik Deskriptif}

Statistik deskriptif digunakan untuk menyajikan data secara deskriptif untuk menggambarkan karakteristik responden, sehingga lebih mudah dipahami dan dintrepretasikan dan dapat digunakan untuk menarik suatu kesimpulan dari hasil penelitian (kuisioner) yang telah dilakukan.

\section{ANALISA DAN PEMBAHASAN}

\section{Profil Responden}

Tabel 1. Usia

\begin{tabular}{lcc}
\hline Jenis Kelamin & Frekuensi & Prosentase \\
\hline $17-25$ tahun & 25 & $25 \%$ \\
$26-35$ tahun & 41 & $41 \%$ \\
$36-45$ tahun & 34 & $34 \%$ \\
\hline Total & 100 & $100 \%$ \\
\hline
\end{tabular}

Tabel 1 menjelaskan bahwa mayoritas responden didominasi oleh kelompok usia dewasa muda (26-25 tahun) sebanyak 41\%, diikuti oleh kelompok usia dewasa akhir (36-45 tahun) sebanyak 34\% dan kelompok usia remaja akhir (17-25 tahun) sebanyak $25 \%$. Hal ini berdasarkan jumlah quota sampling yang digunakan pada penelitian ini menunjukkan bahwa prosentase usia sesungguhnya pada kelompokkelompok yang sudah ditentukan sesuai dengan prosentase responden, yakni remaja akhir sebesar 25\% dari penduduk kota Surabaya, dewasa muda 
sebesar $41 \%$ dari penduduk kota Surabaya, dan dewasa akhir sebesar 34\% dari penduduk kota Surabaya (Sensus Penduduk 2010).

\section{Analisa Deskriptif}

Tabel 2. Crosstab Usia*X1.2

\begin{tabular}{|c|c|c|c|c|c|c|c|}
\hline & & \multicolumn{5}{|c|}{$\begin{array}{l}\text { Makanan organik dapat } \\
\text { menurunkan resiko } \\
\text { penyakit kanker dan } \\
\text { jantung. }\end{array}$} & \multirow[t]{2}{*}{ Total } \\
\hline & & 1 & 2 & 3 & 4 & 5 & \\
\hline \multirow[t]{3}{*}{ Usia } & $\begin{array}{l}17-25 \\
\text { tahun }\end{array}$ & 0 & 1 & 9 & 10 & 5 & 25 \\
\hline & $\begin{array}{l}26-35 \\
\text { tahun }\end{array}$ & 1 & 1 & 6 & 20 & 13 & 41 \\
\hline & $\begin{array}{l}36-45 \\
\text { tahun }\end{array}$ & 0 & 2 & 4 & 22 & 6 & 34 \\
\hline Total & & 1 & 4 & 19 & 52 & 27 & 100 \\
\hline
\end{tabular}

Pada tabel 2 ditampilkan cross-tabulation antara usia dengan pernyataan X1.2 mengenai makanan organik dapat menurunkan resiko penyakit kanker dan jantung. Responden dengan kelompok usia dewasa akhir percaya bahwa dengan memakan makanan organik dapat meminimalisir penyakit kanker dan jatung karena minimnya bahan kimia yang terkandung dalam makanan organik, selain itu makanan organik dinilai bebas dari lemak jahat yang banyak terkandung dalam daging-daging hewan yang diberi suntikan hormon.

Tabel 3. Crosstab Usia*Y2.3

\begin{tabular}{|c|c|c|c|c|c|c|c|}
\hline & & \multicolumn{5}{|c|}{$\begin{array}{c}\text { Makanan organik } \\
\text { merupakan makanan } \\
\text { yang lebih ramah } \\
\text { lingkungan dibanding } \\
\text { makanan konvensional. }\end{array}$} & \multirow[t]{2}{*}{ Total } \\
\hline & & 1 & 2 & 3 & 4 & 5 & \\
\hline \multirow[t]{3}{*}{ Usia } & 17-25 tahun & 0 & 0 & 7 & 12 & 6 & 25 \\
\hline & 26-35 tahun & 0 & 0 & 4 & 29 & 8 & 41 \\
\hline & $36-45$ tahun & 0 & 1 & 2 & 17 & 14 & 34 \\
\hline Total & & 0 & 1 & 13 & 58 & 28 & 100 \\
\hline
\end{tabular}

Tabel 3 menunjukkan kesetujuan responden terhadap makanan organik yang dinilai lebih ramah lingkungan dibanding makanan konvensional. Responden menyatakan bahwa yang menarik perhatian mereka adalah mengkonsumsi makanan organik berdampak baik bagi lingkungan, yaitu ramah lingkungan dan tidak merusak lingkungan sekitarnya. Mereka percaya bahwa tanpa penggunaan bahan kimia yang berlebihan, maka lingkungan yang berada pada daerah pertanian dan peternakan akan subur dan tidak merusak ekosistem yang ada.
Tabel 4

\begin{tabular}{lccccccc}
\hline & & \multicolumn{3}{c}{$\begin{array}{c}\text { Konsumen akan } \\
\text { mereferensikan makanan } \\
\text { organik kepada orang }\end{array}$} & Total \\
& & \multicolumn{5}{c}{ lain. } & \\
\cline { 3 - 7 } & 1 & 2 & 3 & 4 & 5 & \\
\hline Usia & $17-25$ tahun & 0 & 0 & 15 & 8 & 2 & 25 \\
& $26-35$ tahun & 0 & 3 & 7 & 26 & 5 & 41 \\
& $36-45$ tahun & 0 & 1 & 3 & 21 & 9 & 34 \\
\hline Total & & 0 & 4 & 25 & 55 & 16 & 100 \\
\hline
\end{tabular}

Tabel 4 menunjukkan tingkat kesetujuan responden terhadap dimensi kedua minat beli (Z2) yakni minat referensial. Responden dengan kelompok usia dewasa muda dan dewasa akhir lebih cenderung akan mereferensikan makanan organik pada kerabatnya karena maraknya penyakit karena gaya hidup yang tidak sehat dan konsumsi makanan non-organik dengan penguat rasa, penyedap rasa, dan bahkan pewarna yang berlebihan.

\section{Evaluasi Path Coefficient dan Coefficient of Deter- mination $\left(\mathbf{R}^{2}\right)$}

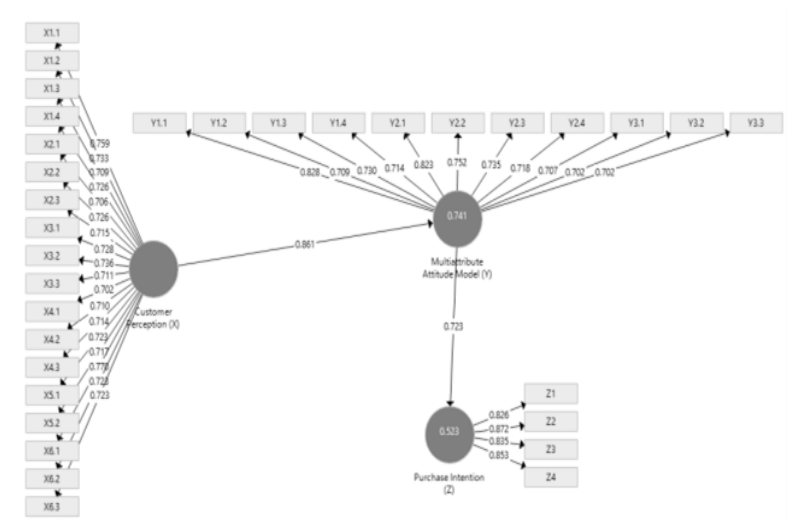

Gambar 2. Path Coefficient dan Coefficient of Determination

Pada analisa path coefficient ini telah terbukti bahwa multiattribute attitude model merupakan variabel intervening yang dimana memperkuat hubungan antara customer perception dengan purchase intention sebesar 0,622503 yang merupakan hasil perkalian antara 0,861 dan 0,723 .

Gambar 1 merupakan bukti bahwa dalam penelitian ini, customer perception harus melalui multiattribute attitude model sebagai variabel intervening agar dapat memperkuat hubungan dengan purchase intention. Selain itu, semua variabel dalam model ini memiliki path coefficient dengan angka yang positif. Sehingga dapat dikatakan, jika semakin besar nilai path coefficient pada suatu variabel independen 
terhadap variabel dependen, maka semakin kuat juga pengaruh antara kedua variabel tersebut.

Nilai coefficient of determination $\left(\mathrm{R}^{2}\right)$ yang di dalam gambar ditunjukkan pada angka yang ada di dalam lingkaran. Dalam lingkaran multiattribute attitude model yang dipengaruhi oleh customer perception, terdapat nilai sebesar 0,741 yang memiliki arti bahwa variabel customer perception mempengaruhi variabel multiattribute attitude model sebesar $74,1 \%$ sedangkan $25,9 \%$ lainnya dipengaruhi oleh variabel lain di luar penelitian ini. Begitu juga dengan variabel purchase intention. Dalam lingkaran purchase intention yang dipengaruhi oleh multiattribute attitude model, terdapat nilai sebesar 0,523 yang memiliki arti bahwa variabel multiattribute attitude model mempengaruhi variabel purchase intention sebesar 52,3\% sedangkan 47,7\% lainnya dipengaruhi oleh variabel lain di luar penelitian ini.

\section{T-statistic}

Tabel 7. T-statistic

\begin{tabular}{|c|c|c|c|c|c|}
\hline & $\begin{array}{c}\text { Original } \\
\text { Sample } \\
\text { (O) }\end{array}$ & $\begin{array}{l}\text { Sample } \\
\text { Mean } \\
\text { (M) }\end{array}$ & $\begin{array}{c}\text { Standard } \\
\text { Deviation } \\
\text { (STDEV) }\end{array}$ & $\begin{array}{c}\text { T-Statistics } \\
(|\mathrm{O} / \mathrm{STDEV}|)\end{array}$ & $\begin{array}{c}\mathrm{P} \\
\text { Value }\end{array}$ \\
\hline$\overline{\mathrm{CP}}(\mathrm{X})$ & & & & & \\
\hline $\begin{array}{l}-> \\
\text { MAM } \\
\text { (Y) }\end{array}$ & 0.861 & 0.863 & 0.044 & 19.740 & 0.000 \\
\hline $\begin{array}{l}\text { MAM } \\
\text { (Y) -> } \\
\text { PI (Z) }\end{array}$ & 0.723 & 0.729 & 0.046 & 15.627 & 0.000 \\
\hline
\end{tabular}

Tabel 4.30 memiliki arti bahwa nilai original sample (O) adalah nilai path coefficient yang menunjukkan kekuatan pengaruh satu variabel laten ke variabel laten lainnya. Nilai pada kolom sample mean (M) menunjukkan nilai tengah dari path coefficient. Nilai pada kolom standart deviation (STDEV) menunjukkan nilai simpang pada sample mean. Nilai pada kolom $T$-statistic digunakan untuk melihat nilai hitung $\mathrm{T}$ yang akan digunakan pada pengujian hipotesis dengan syarat nilai T-statistic harus $>1,96$.

$T$-statistic pada pengaruh customer perception terhadap multiattribute attitude model menunjukkan nilai 19,740 yang artinya customer perception berpengaruh signifikan terhadap multiattribute attitude model. Selanjutnya, T-statistic pada pengaruh multiattribute attitude model terhadap purchase intention menunjukkan nilai 15,627 yang artinya multiattribute attitude model berpengaruh signifikan terhadap purchase intention.

\section{PEMBAHASAN}

\section{Customer Perception terhadap Multiattribute Atti- tude Model}

Penelitian ini memiliki hasil bahwa customer perception pada makanan organik memiliki pengaruh terhadap sikap konsumen dalam multiattribute attitude model secara signifikan dengan nilai uji $T$ statistic $>1,96$ yaitu 19,740 .

Penelitian ini mempunyai hasil yang menunjukkan bahwa customer perception berpengaruh signifikan terhadap sikap konsumen dalam multiattribute attitude model, dimana sesuai dengan pendapat bahwa persepsi konsumen akan membentuk suatu sikap tertentu terhadap suatu objek (Abdourrahmane \& Sukhabot, 2014; Budiman, 2012; Kim \& Chung, 2011; Scotia et al., 2006; Yang et al., 2014).

Dalam penelitian ini dapat dibuktikan bahwa persepsi konsumen terhadap makanan organik, mempunyai pengaruh yang besar dalam pengambilan sikap konsumen terhadap makanan organik. Dengan memiliki persepsi yang cukup, dapat secara signifikan mempengaruhi sikap konsumen tersebut dalam menilai makanan organik. Persepsi konsumen merupakan tahap awal dalam proses pembelian. Setelah tahap itu selesai dipahami oleh seseorang, maka akan terbentuk ouput atau hasil evaluasi persepsi dalam bentuk sikap. Persepsi tersebut akan mempengaruhi sikap-sikap yang dikeluarkan konsumen baik secara positif maupun negatif. Persepsi konsumen yang dimiliki dalam penelitian ini merupakan persepsi yang positif, sehingga konsumen mempunyai sikap yang baik terhadap makanan organik karena dinilai memberikan keuntungan positif bagi konsumen itu sendiri. Hal ini sebagai pembuktian dari teori yang diajarkan oleh Schiffman \& Kanuk (2007).

Dari hasil penelitian ini, peneliti membuat beberapa cara untuk menggugah persepsi masyarakat menjadi suatu sikap terhadap makanan organik, yaitu: a. Gerakan TOLAK 4P-G

Gerakan ini bertajuk menolak bahan-bahan kimia seperti penyedap rasa atau penguat rasa dan aroma, pewarna, pengawet, pemanis buatan dan GMO atau rekayasa genetika. Gerakan TOLAK 4P-G merupakan sebuah gerakan kesehatan untuk lebih memudahkan kinerja tubuh. Makanan tanpa bahan kimia yang belebihan membuat kinerja ginjal dan jantung menjadi lebih mudah karena tidak mengandung zat-zat berbahaya yang dapat membuat ginjal bekerja keras dan membuat darah kental. Gerakan ini dapat ditujukan pada semua konsumen, terutama kelompok usia dewasa muda dan dewasa akhir yang sudah mempunyai anak. 
Diketahui bahwa responden dengan kelompok usia tersebut lebih setuju untuk menggunakan makanan organik sebagai bahan dasar MP-ASI karena dapat meningkatkan sistem imun tubuh anak mereka bahkan juga diri mereka sendiri, selain itu, dengan gerakan tolak 4P-G, dapat ditunjukkan bahwa makanan organik aman dikonsumsi oleh siapapun, baik oleh orang dewasa maupun balita sekalipun yang disetujui oleh $90 \%$ responden dari seluruh kelompok usia.

b. Garden to Table Campign

Kampanye ini diadaptasi dari gerakan Jakarta Berkebun adalah bertujuan untuk menghijaukan kota sekaligus memasak makanan organik dengan menggunakan bahan yang ditanam sendiri tanpa khawatir dengan penggunaan pestisida. Gerakan ini juga bisa ditujukan untuk konsumen berusia remaja akhir hingga dewasa muda, karena gerakan ini lebih bagus dan lebih menyenangkan dibanding berolahraga di gym. Dengan berkebun di pagi hari, peserta yang ikut tentu saja akan terpapar sinar matahari sehingga baik untuk kekuatan tulang selain itu, dengan mengangkat pot-pot tanaman yang berat sama dengan mengangkat alat berat yang ada pada ruangan gym. Jadi, konsumen dapat mendapatkan gizi yang baik dari makanan organik, juga berolahraga, dan tidak lupa lagi adalah menjaga keseimbangan ekosistem dengan berkebun tanpa menggunakan pestisida.

c. Gerakan Clean Eating

Gerakan clean eating bisa dimanfaatkan oleh para produsen/penjual makanan organik. Gerakan ini dapat dilakukan minimal sebulan sekali selama satu minggu. Clean eating merupakan gerakan dengan mengkonsumsi makanan organik selama satu minggu penuh. Dengan gerakan ini, konsumen dapat menurunkan resiko penyakit jantung dan obesitas. Gerakan ini cocok untuk mereka yang mempunyai keinginan untuk melakukan diet lemak, karena makanan organik sama sekali tidak mengandung lemak hidrogenasi yang biasanya dimiliki oleh makanan nonorganik. Jenis lemak tersebut bisa meningkatkan resiko penyakit jantung. Selain itu, gerakan ini menjauhkan konsumen dari pestisida yang terkandung dalam makanan non-organik. Gerakan ini dilakukan untuk membuktikan secara pasti persepsi konsumen mengenai makanan organik yang dapat mengurangi resiko penyakit jantung, kanker, dan obesitas. Diketahui bahwa responden dengan kelompok usia dewasa akhir sudah mulai memikirkan lebih lagi mengenai masalah kesehatan tubuhnya terlebih pada penyakit kanker dan jantung, sedangkan responden dengan kelompok usia lainnya lebih cenderung pada obesitas, oleh karena itu, gerakan clean eating ini dapat dilakukan untuk menjawab permasalahan konsumen mengenai kesehatan mereka terutama jantung, kanker, dan obesitas.

\section{d. Organic food is a tasty food campign}

Slogan tersebut merupakan sebuah slogan yang dapat menunjukkan bahwa rasa makanan organik tidak kalah lezat dibanding makanan non-organik. Responden dengan kelompok usia remaja akhir menyatakan bahwa makanan organi tidak memiliki rasa yang kuat (hambar). Hal ini dapat dipatahkan oleh penjual/produsen dengan menunjukkan atau memberikan makanan organik yang sudah dipanen. Makanan organik, sesuai dengan standar kualitasnya, memiliki rasa yang lebih alami karena makanan organik dipanen ketika bahan makanan sudah benar-benar matang. Sedangkan makanan non-organik yang memiliki rasa lebih kuat, dipanen ketika masih muda dan diberi tambahan bahan kimia untuk membantu mempercepat kematangannya, sehingga dapat mempengaruhi rasa bahan makanan dan makanan menjadi terkontaminasi bahan kimia. Selain itu, bahan makanan organik tidak dapat bertahan lama karena tidak mengandung bahan kimia (pengawet) sama sekali. Oleh karena itu, bahan makanan organik perlu diolah ketika masih baru, sehingga menghasilkan rasa yang alami dan segar.

\section{Multiattribute Attitude Model terhadap Purchase Intention}

Penelitian ini memiliki hasil bahwa multiattribute attitude model pada makanan organik memiliki pengaruh terhadap purchase intention secara signifikan dengan nilai uji $T$-statistic $>1,96$ yaitu 15,627.

Penelitian ini mempunyai hasil yang menunjukkan bahwa multiattribute attitude model berpengaruh secara signifikan terhadap purchase intention dimana hal ini sesuai dengan pendapat bahwa sikap konsumen yang semakin positif terhadap suatu objek, maka akan memperbesar kemungkinan konsumen membeli objek tersebut (Abdourrahmane \& Sukhabot, 2014; Kim \& Chung, 2011; Yang et al., 2014).

Dalam penelitian ini dapat dibuktikan bahwa sikap konsumen terhadap makanan organik mempunyai pengaruh dalam menggugah minat beli seseorang yang dapat berujung pada pembelian aktual. Penelitian ini juga menunjukkan minat beli konsumen dalam makanan organik bukan terdapat hanya pada minat transaksional saja, melainkan juga pada minat referensial, minat preferensial, dan minat eksploratif, dimana minat-minat tersebut lebih dominan berada 
pada responden dengan kategori umur dewasa muda dan dewasa akhir.

Dari hasil penelitian ini, peneliti membuat beberapa cara untuk menggugah minat beli masyarakat terhadap makanan organik, yaitu:

a. How to cook properly on your organic food? (Event)

Dengan melakukan acara edukasi mengenai cara memasak, produsen/penjual makanan organik dapat secara tidak langsung menunjukkan cara mereka memproduksi makanan organik. Makanan organik jika diproduksi dengan cara yang salah, maka akan menghilangkan nutrisi dan membuat bahan makanan organik ini tidak memiliki kelebihan apa-apa. Makanan organik jika dimasak terlalu lama (digoreng atau direbus) hanya akan membuat nutrisinya hilang, sehingga makanan organik harus dimasak dengan waktu dan suhu yang pas supaya nutrisi yang terkandung dalam makanan organik tidak hilang. Event ini dapat dilakukan untuk menggugah minat eksploratif konsumen sebagai sarana untuk menggugah pembelian aktual konsumen pada makanan organik. Dinyatakan dalam hasil penelitian bahwa lebih dari 50\% responden dari semua kelompok usia setuju untuk mencari informasi terbaru mengenai makanan organik, sehingga event ini dapat diselenggarakan untuk memfasilitasi minat eksploratif dari konsumen makanan organik.

b. Healthy inside fresh outside campaign

Terinspirasi dari tagline sebuah produk minuman bervitamin, makanan organik bertujuan menghasilkan hasil yang sama dengan minuman tersebut. Makanan organik merupakan makanan yang bebas dari bahan kimia, sehingga baik untuk kesehatan tubuh, jantung, dan baik untuk penderita obesitas. Dengan gerakan ini, produsen/penjual dapat menunjukkan bahwa dengan mengkonsumsi makanan organik, dapat memperlancar aliran darah, mempermudah kinerja ginjal sehingga tubuh tidak perlu bekerja keras dan dapat memberikan tubuh yang sehat dan bugar setiap harinya. Gerakan ini dapat dilakukan pada konsumen dengan kelompok usia remaja akhir, karena diketahui bahwa sebesar 52\% responden lebih bersikap netral ketika diperhadapkan dengan keputusan untuk membeli makanan lagi. Diketahui bahwa mereka lebih menyukai memakan makanan non-organik yang diimbangi dengan olahraga (gym), oleh karena itu, gerakan ini dibuat agar konsumen dengan usia remaja akhir dapat lebih memelihara tubuhnya lebih baik lagi dengan mengkonsumsi makanan organik.

\section{KESIMPULAN DAN SARAN}

\section{Kesimpulan}

Berdasarkan penelitian diatas, dapat dilihat bahwa customer perception merupakan sebuah prediktor penting yang secara statistik berpengaruh signifikan terhadap multiattribute attitude model sebagai variabel intervening pada purchase intention. Hal ini ditunjukkan oleh sebagian besar responden yang setuju bahwa persepsi mereka dapat mempengaruhi sikap mereka terhadap makanan organik, yang mana sikap tersebut dapat mempengaruhi minat beli masyarakat terhadap makanan organik. Berdasarkan path coefficient menunjukkan bahwa hubungan customer perception dengan multiattribute attitude model dan hubungan multiattribute attitude model dengan purchase intention memiliki hubungan yang kuat.

Sehingga dalam makanan organik akan terjadi pembelian nyata apabila persepsi masyarakat terhadap makanan organik terpenuhi dengan baik dan ada sikap positif yang ditunjukkan masyarakat terhadap makanan organik sehingga mempengaruhi minat beli masyarakat. Oleh karena itu, penjual maupun produsen makanan organik dapat memperhatikan persepsi masyarakat terhadap makanan organik dan dapat memenuhi persepsi tersebut agar masyarakat mempunyai sikap yang positif terhadap makanan organik yang dapat menggugah minat beli masyarakat pada makanan organik tersebut.

\section{DAFTAR PUSTAKA}

Abdillah, W., \& Hartono, J. (2015). Partial Least Square (PLS): Alternatif Structural Equation Modeling (SEM) dalam Penelitian Bisnis. Yogyakarta: Andi.

Abdourrahmane, M., \& Sukhabot, S. (2014). An International Consumer's Perception and Attitude towards the Purchase Intentions of OTOP Snack Food Products. TNI Journal of Business Administration and Languages, 2(1), 54-60.

Asiegbu, I. F., Powei Daubry M, \& Iruka, C. (2012). Consumer Attitude: Some Reflections on Its Concept, Trilogy, Relationship with Consumer Behavior, and Marketing Implications. European Journal of Business and Management, 4(13), 38-50. Retrieved from http://www.iiste. org/Journals/index.php/EJBM/article/viewFile/2 $02 / 2726$

Budiman, S. (2012). Analysis of Consumer Attitudes to Purchase Intentions of Counterfeiting Bag Product in Indonesia. International Journal of 
Management, Economics and Social Sciences, 1(1), 1-12. Retrieved from http://www.ijmess. com/volumes/volume-I-2012/issue-I-05-2012/ full-1.pdf

Indonesia Organic Alliance. (2017). Permintaan Produk Pertanian Organik Makin Meningkat. Retrieved February 28, 2017, from http://organicindonesia.org/aoi/permintaan-produk-pertanianorganik-makin-meningkat/

Jaafar, S. N., Lalp, P. E., \& Mohamed Naba, M. (2013). Consumers' Perceptions, Attitudes and Purchase Intention towards Private Label Food Products in Malaysia. Asian Journal of Business and Management Sciences, 2(8), 73-90.

Kim, H. Y., \& Chung, J.-E. (2011). Consumer purchase intention for organic personal care products. Journal of Consumer Marketing, 40-47. https://doi.org/10.1108/07363761111101930

Kotler, P., \& Amstrong, G. (2010). Principle of Marketing (Thirteenth). United States of America: Pearson Prentice Hall.

Novandari, W. (2011). Analisis Motif Pembelian Dan Profil Perilaku "Green Product Customer" (Studi Pada Konsumen Produk Pangan Organik di Purwokerto). JEBA, 13(1), 17-23.

Peter, J. P., \& Olson, J. C. (2008). Consumer Behavior and Marketing Strategy (Eighth Edi). Singapore: Mc Graw Hill.

Schiffman, L. G., \& Kanuk, L. L. (2007). Consumer Behavior (Ninth Edit). United States of America: Pearson Prentice Hall.
Scotia, N., Bonti-ankomah, S., Yiridoe, E. K., Chain, A., Risk, I., Analysis, M., \& Canada, A. (2006). Organic and Conventional Food: A Literature Review of the Economics of Consumer Perceptions and Preferences, (APRIL 2006), 1-40. Retrieved from http://www.organicagcentre.ca/ Docs/BONTI \& YIRIDOE April 282006 Final. pdf

Solomon, M. R. (2004). Consumer Behavior (Sixth Edit). United States of America: Pearson Prentice Hall.

Vermeir, I., \& Verbeke, W. (2006). Sustainable food consumption: Exploring the consumer "attitude Behavioral intention" gap. Journal of Agricultural and Environmental Ethics, 19(2), 169-194. https://doi.org/10.1007/s10806-005-5485-3

Wee, C. S., Ariff, M. S. B. M., Zakuan, N., \& Tajudin, M. N. M. (2014). Consumers Perception, Purchase Intention and Actual Purchase Behavior of Organic Food Products. Review of Integrative Business \& Economics, 3(2), 378397.

Yang, M., Al-shaaban, S., \& Nguyen, T. B. (2014). Consumer Attitude and Purchase Intention towards Organic Food A quantitative study of China Linnæus University. Journal of Consumer Behaviour, 6(2C), 1-67.

Yayasan Pengembangan Kemanusiaan Donders. (2015). Permintaan Pasar Meningkat Pesat, Tapi Stok Terbatas. Retrieved February 28, 2017, from http://www.dondersfoundation.org/?p=125 